\title{
ОКИСНА ДЕСТРУКЦІЯ БІЛКІВ ПРИ ГІПОКСИЧНО-ІШЕМІЧНИХ УРАЖЕННЯХ ГОЛОВНОГО МОЗКУ НА ЕТАПАХ КАРДІОХІРУРГІЧНИХ ВТРУЧАНЬ З ВИКОРИСТАННЯМ ШТУЧНОГО КРОВООБІГУ
}

\author{
Державна установа «Інститут серця МОз україни», Київ \\ ๑Д. С. Маньковський
}

РЕзЮМЕ. Роль вільнорадикального окиснення білків крові в механізмах розвитку гіпоксично-ішемічних уражень (ГІУ) головного мозку (ГМ) та у ефективності функціонування гематоенцефалічного бар'єру (ГЕБ) залежить від ендотеліальних клітин, астроцитів і перицитів, порушення функцій яких викликає дисфункцію ГЕБ, зокрема за рахунок окиснення білкових фрагментів.

Мета - вивчення особливостей окиснення білкових фрагментів клітин та нуклеїнових кислот у пацієнтів з гіпоксично-ішемічними ураженнями до та після кардіохірургічних втручань з використанням штучного кровообігу.

Матеріал і методи. Наведені результати обстеження 38 пацієнтів з гіпоксично-ішемічними ураженнями головного мозку після кардіохірургічних втручань; діагностику неврологічного статусу виконували згідно з клінічними протоколами. Метаболічні зміни щодо окисної модифікації білків (ОМБ) та нуклеїнових кислот (ОМНК) досліджено у спонтанних та індукованих $\left(\mathrm{Fe}^{++}\right)$реакціях на доопераційному (за 3-5 діб) та післяопераційному (через 5-7 діб) етапах. Вивчено вміст білкових компонентів у сироватці крові - 2,4 - динітрофенілгідрозонів (ДНФГ).

Результати. Спонтанна ОМБ на етапах КХВ характеризується достовірними $(p<0,001)$ змінами у накопиченні як альдегідних, так і карбонільних продуктів, а також у зміні ступеня (глибини) деструкції білків. В індукованих реакціях ОМБ виявлено зростання (з $(0,303 \pm 0,007)$ у.о./мг білка до $(0,396 \pm 0,003)$ у.о./мг білка) ступеня (глибини) деструкції білка за рахунок білкових фрагментів середнього розміру та достовірного збільшення питомої ваги фрагментів малого розміру, що $є$ найінформативнішою ознакою впливу на метаболічні резерви ОМБ у хворих.

Висновки. На етапах кардіохірургічного втручання формуються передумови, що сприяють інтенсифікації процесу ОМБ плазми крові та ОМНК. Особливістю змін стану ОМНК та ОМБ $\epsilon$ найбільш виразне зростання їх вмісту в післяопераційний період на тлі відносного зростання вмісту альдегідних та карбонільних продуктів окиснення з перерозподілом ступеня (глибини) ОДБ в спонтанних та, особливо, в індукованих реакціях. Наведене свідчить про зростання проявів деструкції та інтенсифікації ОМБ при одночасному накопиченні резервів окиснення білкових фрагментів плазми крові в післяопераційному періоді. білків.

КлючОВІ СлОВА: гіпоксично-ішемічні ураження головного мозку; кардіохірургія; окисна модифікація

Вступ. Гіпоксично-ішемічні ураження (ГІУ) головного мозку (ГМ) у кардіохірургічних пацієнтів, насамперед у випадках використання штучного кровообігу (ШК) $є$ нагальною проблемою клінічної неврології, кардіохірургії та інтенсивної терапії $[1,2]$. Відомі дослідження з цієї проблематики акцентують увагу на ролі низки факторів ризику ГІУ ГМ: передопераційного соматичного стану [3], неврологічного статусу [4], клініко-анамнестичних та інтраопераційних факторів та можливих механізмів ГІУ ГМ унаслідок кардіохірургічного втручання (КХВ) [5]. Одним із універсальних механізмів, що призводить до патології клітин, вважають розвиток окисного стресу (ОС), як неспецифічної реакції окиснювального гомеостазу (ОГ), тоді як ГМ особливо чутливий до окисного пошкодження внаслідок його високої швидкості споживання кисню, надлишкового вмісту ліпідів та відносної недостатності антиоксидантних ферментів, порівняно з іншими тканинами [6]. Уявлення про можливість вільнорадикальної модифікації та деструкції білків в організмі досі мали переважно теоретичний характер. У ряді робіт цей процес розглядається як одна з важливих ві- рогідних причин інактивації ферментів, змін структурної організації білків в умовах ОС. Окисна модифікація N-кінцевої частини амінокислоти білків може спричиняти виникнення в них антигенних властивостей та ініціації аутоімунного процесу до власних білків організму. У доступній літературі відсутні дані про роль вільнорадикального окиснення білків крові в механізмах розвитку ОС при ГІУ ГМ. Водночас, ефективність функціонування гематоенцефалічного бар'єру (ГЕБ) залежить від ендотеліальних клітин, астроцитів і перицитів, порушення функцій яких викликає дисфункцію ГЕБ [7]. При цьому ефекти гіпоксії передбачають загальну супресію обміну речовин, особливо киснезалежних шляхів продукції АТФ i, отже, тих шляхів, які залежать від споживання АТФ. Первинне зниження рівня високоенергетичних фосфатів провокує гальмування $\mathrm{Na}^{+} / \mathrm{K}^{+}$насосу, який залежить від АТФ, його порушення сприяє накопиченню внутрішньоклітинного $\mathrm{Na}^{+}, \mathrm{Ca}^{+}$і води, що призводить до утворення цитотоксичного набряку. Ці події сприяють деполяризації мембран та підвищеному вивільненню збудливих нейротрансмітерів, особливо глутамату. Аци- 
Огляди літератури, оригінальні дослідження, погляд на проблему, випадок з практики, короткі повідомлення

доз впливає на продукцію АТФ в астроцитах i, отже, він має наслідки для нормального поглинання глутамату, що є суттєвим, особливо під час гіпоксичної ішемії, через посилення накопичення глутамату $[8,9]$.

Мета - вивчення особливостей окиснення білкових фрагментів клітин та нуклеїнових кислот у пацієнтів з ГІУ ГМ до та після КХВ з використанням ШК.

Матеріал і методи дослідження. Обстежено 38 пацієнтів з ГІУ ГМ після КХВ з використанням ШК, зокрема з ішемічним інсультом - 14 осіб, енцефалопатією - 15 осіб, тяжкою когнітивною дисфункцією - 9 осіб; діагностику неврологічного статусу виконували згідно з клінічними протоколами. Метаболічні зміни щодо окисної модифікації білків (ОМБ) та нуклеїнових кислот (ОМНК) досліджено у спонтанних та індукованих $\left(\mathrm{Fe}^{++}\right)$реакціях, що дозволило визначитись стосовно метаболічних змін. Клініко-біохімічне дослідження виконано на доопераційному (за 3-5 діб) та післяопераційному (через 5-7 діб) етапах КХВ. Вивчено вміст білкових компонентів у сироватці крові -2,4 - динітрофенілгідразонів (ДНФГ) та альдегідних і карбонільних продуктів ОМБ у спонтанних та індукованих. Оцінка ОМБ базувалася на реакції взаємодії окислених амінокислотних залишків 3 2,4-динітрофенілгідразином і утворенні ДФНГ [10]. При цьому для оцінки ступеня окисної деструкції визначали (залежно від довжини хвилі спектрофотометра) дрібні ( $\lambda=254$ нм) ОМБ, виявлені в індукованих реакціях $\left(I_{д}\right)$, середні ( $\lambda=270$ нм) ОМБ, виявлені в індукованих реакціях $\left(I_{C}\right)$, крупні $(\lambda=280$ нм) ОМБ, виявлені в індукованих реакціях $\left(\mathrm{I}_{\mathrm{K}}\right)$ та аналогічні показники у спонтанних реакціях $\left(\mathrm{C}_{\mathrm{K}}, \mathrm{C}_{\mathrm{C}} \mathrm{C}_{\mathrm{g}}\right)$. Для оцінки ступеня дефрагментації окиснених білків плазми використовували надопадову рідину, в якій спектрофотометрично виявляли пептиди при визначених довжинах хвиль $[10,11]$. Індуковану ОМБ забезпечено шляхом використання середовища Фентона (0,1 М фосфатний буфер, $\mathrm{pH}=7,4$, який містить один ммоль $\mathrm{FeSO}_{4}$ та 40,3 ммоль $\mathrm{H}_{2} \mathrm{O}_{2}$ ) $з$ подальшою процедурою підготовки та спектрофотометрії надопадової рідини. Ступінь ОМБ виражали в одиницях оптичної густини на мг білка. Рівень вмісту ОМНК оцінювали за їх екскреторним індикатором - за вмістом 8-гідроксигуаніну у добовій сечі методом хроматографії на пластинках "Силуфолф" [11]; у якості хроматографічного стандарту застосовано 8-гідроксигуанін з подальшим перерахунком за стандартизованою процедурою у нмоль/л. Для розрахунків застосовано стандартні методики з використанням адаптованої до середовища «EXCEL» програми [12].

Результати й обговорення. Спонтанна ОМБ на етапах КХB характеризується достовірними
( $p<0,001)$ змінами у накопиченні як альдегідних, так і карбонільних продуктів, а також у зміні ступеня (глибини) деструкції білків. Найвиразнішим у системі показників сОМБ є зростання вмісту $(p<0,001)$ альдегідних продуктів з $(66,67 \pm 0,77)$ у.о./мг білка до $(82,12 \pm 0,35)$ у.о./мг білка, що пояснюється зростанням загальної кількості спонтанно окисномодифікованих білків з $(1,990 \pm 0,013)$ у.о./мг білка до $(2,219 \pm 0,011)$ у.о./мг білка та глибини окисної модифікації переважно за рахунок зростання білкових фрагментів крупного розміру (які виявляються при $\lambda=280$ нм). Серед показників сОМБ найвищими індексами змін характеризуються показник вмісту альдегідних продуктів та показник абсолютного вмісту сОМБ крупного розміру (табл. 1). Питома вага внеску кожного із досліджених метаболічних показників до загального ефекту коливається у межах $(0,8 \div 1,5) \%$.

ОМБ у індукованих реакціях також характеризується достовірними ( $<<0,05)$ змінами у накопиченні як альдегідних, так і карбонільних продуктів, та у зміні ступеня (глибини) деструкції білків. Загальна кількість іОМБ під впливом лікування достовірно $(p<0,05)$ зросла з $(2,504 \pm 0,018)$ у.о./мг білка до $(2,913 \pm 0,011)$ у.о./мг білка, що свідчить про зростання резервів для можливої спонтанної модифікації білків.

В індукованих реакціях ОМБ виявлено зростання (з $(0,303 \pm 0,007)$ у.о./мг білка до $(0,396 \pm$ 0,003) у.о./мг білка) ступеня (глибини) деструкції білка за рахунок білкових фрагментів середнього розміру та достовірного збільшення питомої ваги фрагментів малого розміру, що $є$ найінформативнішою ознакою впливу на метаболічні резерви ОМБ у хворих. Метаболічні показники індукованої реакції ОМБ характеризуються низькою питомою вагою в загальному пулі впливу та коливаються у межах $(1,0 \div 1,5) \%$.

Вміст ОМНК, оцінюваний за показником екскреції 8-гідроксигуаніну з сечею хворих, під впливом КХВ достовірно $(p<0,001)$ зріс - $3(0,224 \pm$ $0,012)$ нмоль/дм ${ }^{3}$ до $(0,542 \pm 0,005)$ нмоль/дм ${ }^{3}$ та, зважаючи на найвиразніше значення клінічного індексу цього метаболіту $\left(\mathrm{KIE}_{\mathrm{HK}}=0,41 \pm 0,02\right)$, має найбільший метаболічний ефект $\left(\mathrm{AOE}_{\mathrm{HK}}=2,7 \pm 0,1 \%\right)$ та перше рангове місце в системі ОМБ.

Висновки. 1. На етапах КХВ з використанням ШК формуються передумови, що сприяють інтенсифікації процесу ОМБ плазми крові та ОМНК, що слід розглядати у контексті загальної концепції реалізації ГІУ ГМ. 2. Особливістю змін стану ОМНК та ОМБ $є$ найвиразніше зростання їх вмісту в післяопераційний період на тлі відносного зростання вмісту альдегідних та карбонільних продуктів окиснення з перерозподілом ступеня (глибини) ОДБ в спонтанних та, особливо, в індукованих ре- 
Огляди літератури, оригінальні дослідження, погляд на проблему, випадок з практики, короткі повідомлення

Таблиця 1. Спонтанна та індукована окисна модифікація білків мембран клітин у пацієнтів з гіпоксично-ішемічними ураженнями головного мозку до та після кардіохірургічних втручань

\begin{tabular}{|c|c|c|c|c|c|c|c|}
\hline & Показники окисної м & १фікаціі & еструкції & & Показники & & \\
\hline & нуклеїнових & слот і 6 & & $\mathrm{MI}$ & MK & ME & 陏 \\
\hline & 2,4 ДНФГ: $\lambda=270$ нм, & після & $82,12 \pm 0,35$ & $0,81 \pm 0,01$ & $0,071 \pm 0,003$ & $1,4 \pm 0,1$ & 5,5 \\
\hline & & до & $66,67 \pm 0,77^{\mathrm{a}}$ & & & & \\
\hline & 2,4 ДНФГ: $\lambda=363$ нм, & після & $100,3 \pm 0,59$ & $0,85 \pm 0,01$ & $0,057 \pm 0,003$ & $1,2 \pm 0,1$ & 8,5 \\
\hline & & до & $85,08 \pm 0,84^{a}$ & & & & \\
\hline 等 & 2,4 ДНФГ: & після & $1,869 \pm 0,011$ & $0,91 \pm 0,01$ & $0,036 \pm 0,002$ & $0,8 \pm 0,1$ & 11 \\
\hline 통 & $\mathrm{C}_{\mathrm{M}^{\prime}}$ НМОЛЬ/ДМ & до & $1,704 \pm 0,014^{\mathrm{a}}$ & & & & \\
\hline & 2,4 ДНФГ: & після & $0,240 \pm 0,004$ & $0,82 \pm 0,01$ & $0,068 \pm 0.003$ & $1,4 \pm 0,1$ & 5,5 \\
\hline & $C_{c^{\prime}}$ НМОЛЬ/ДМ & до & $0,195 \pm 0,004^{a}$ & & & & \\
\hline & 2,4 ДНФГ: & після & $0,110 \pm 0,001$ & $0,81 \pm 0,01$ & $0,071 \pm 0,003$ & $1,5 \pm 0,1$ & 2,5 \\
\hline & $C_{K}$, НМОЛЬ/ДМ & до & $0,090 \pm 0,013^{a}$ & & & & \\
\hline & & & $\begin{array}{l}\text { 1онтанна окись } \\
\text { дифікація білк }\end{array}$ & & $0,073 \pm 0,002$ & $1,50 \pm 0,04$ & - \\
\hline & 2,4 ДНФГ: $\lambda=270$ нм, & після & $763,9 \pm 4,96$ & $0,81 \pm 0,01$ & $0,071 \pm 0,004$ & $1,4 \pm 0,1$ & 5,5 \\
\hline & 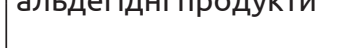 & до & $621,5 \pm 1,02^{a}$ & & & & \\
\hline & 2,4 ДНФГ: $\lambda=363$ нм, & після & $697,3 \pm 5,38$ & $0,83 \pm 0,01$ & $0,063 \pm 0,004$ & $1,2 \pm 0,1$ & 8,5 \\
\hline & КароонІЛЬнІ продукіИ & до & $582,8 \pm 9,04^{a}$ & & & & \\
\hline 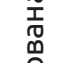 & 2,4 ДНФГ: & після & $2,202 \pm 0,010$ & $0,89 \pm 0,01$ & $0,046 \pm 0,002$ & $1,0 \pm 0,1$ & 10 \\
\hline 产 & 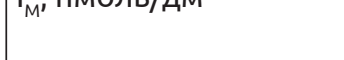 & до & $1,949 \pm 0,015^{a}$ & & & & \\
\hline & 2,4 ДНФГ: & після & $0,396 \pm 0,003$ & $0,77 \pm 0,02$ & $0,076 \pm 0,006$ & $1,5 \pm 0,1$ & 2,5 \\
\hline & ${ }_{C}, \mathrm{HMO}$ & до & $0,303 \pm 0,007^{a}$ & & & & \\
\hline & 2,4 ДНФГ: & після & $0,316 \pm 0,003$ & $0,80 \pm 0,01$ & $0,074 \pm 0,003$ & $1,5 \pm 0,1$ & 2,5 \\
\hline & I, HIV & до & $0,252 \pm 0,003^{a}$ & & & & \\
\hline & & & $\begin{array}{l}\text { дукована окис } \\
\text { одифікація біл }\end{array}$ & & $0,066 \pm 0,003$ & $1,31 \pm 0,05$ & - \\
\hline & 8-гідроксигуанін, & після & $0,542 \pm 0,005$ & $0,41 \pm 0,02$ & $0,133 \pm 0,004$ & $2,7 \pm 0,1$ & 1 \\
\hline$\sum_{0}^{T}$ & нмоль/дм³ & до & $0,224 \pm 0,012$ & & & & $\widehat{\jmath}$ \\
\hline
\end{tabular}

Примітки: 1. MI-метаболічний індекс; 2. MK-метаболічний коефіцієнт (MK=- MI(log2MI), біт); 3. ME-метаболічний ефект (питома вага в \%); 4. $\rho$ - ранг змін (стрілкою - напрямок змін показника); 5. а-достовірність ефекту при р<0,001.

акціях. Наведене свідчить про зростання проявів деструкції та інтенсифікації ОМБ при одночасному накопиченні резервів окиснення білкових фрагментів плазми крові в післяопераційному періоді КХВ. 3. Виходячи із виявлених закономір- ностей, інтенсифікацію ОМБ в післяопераційному періоді КХВ зі ШК слід розглядати у системі патогенетичних механізмів ГІУ ГМ з розробкою відповідних лікувально-корекційних заходів (програм профілактики). 


\section{ЛІТЕРАТУРА}

1. Тодуров Б. М. Порушення функції центральної нервової системи після операцій зі штучним кровообігом у пацієнтів з низькою фракцією викиду лівого шлуночка / Б. М. Тодуров, І. М. Кузьмич, О. О. Тарабрін // Клінічна анестезіологія та інтенсивна терапія. - 2015. № 2 (6). - C. 82-90.

2. Minimized extracorporeal circulation does not impair cognitive brain function after coronary artery bypass grafting / D. Reineke, B. Winkler, T. Konig [et al.] // Interactive Cardiovascular and Thoracic Surgery. - 2015. Vol. 20 (1). - P. 68-73.

3. Маньковський Д. С. Гіпоксично-ішемічні ураження головного мозку: прогностична цінність клініко-анамнестичних факторів для оцінки їх ризику при кардіохірургічних втручаннях з використанням штучного кровообігу / Д. С. Маньковський // The world of science and innovation. 12th International scientific and practical conference (01-03 July 2021, London, United Kingdom). Cognum Publishing House. London, United Kingdom. - 2021. P. 232-237.

4. Маньковський Д. С. Церебральний кровообіг та фактори ризику формування гіпоксично-ішемічних уражень головного мозку у кардіохірургічних пацієнтів при використанні штучного кровообігу / Д. С. Маньковський // Вітчизняна наука - перспективи та інновації : Збірник тез наукових робіт міжнародної науковопрактичної конференції (м. Київ, 9-10 липня 2021 р.). Київ : ГО "Київський медичний науковий центр", 2021. - C. 22-26.

5. An N. Difficulties in Understanding Postoperative Cognitive Dysfunction / N. An, W.F. Yu // Journal of Anesthesia \& Perioperative Medicine. -2017. - Vol. 4. - P. 87-94.
6. Scharbarg E. Astrocyte-derived adenosine is central to the hypnogenic effect of glucose / E. Scharbarg, M. Daenens, F. Lemaitre // Scientific Reports. - 2016. Vol. 6. - P. 191-207. DOI: 10.1038/srep19107

7. A pilot study of cerebral tissue oxygenation and postoperative cognitive dysfunction among patients undergoing coronary artery bypass grafting randomised to surgery with or without cardiopulmonary bypass / W. F. Kok, A. E. van Harten, B. M. Koene [et al.] // Anaesthesia. 2014. - Vol. 69 (6). - P. 613-622.

8. Остапченко Л. І. Біохімічні механізми загибелі клітин: молекулярні механізми загибелі клітин : курс лекцій зі спецкурсу / Л. І. Остапченко, Д. М. Гребіник. Київ : ННЦ «Інститут біології», 2014. - 100 с.

9. Молекулярні механізми розвитку енцефалопатії : монографія [Г. О. Ушакова, Я. В. Бабець, С. В. Кириченко]; за ред. проф. Г. О. Ушакової. - Дніпро : ДНУ імені Олеся Гончара, 2017. - 203 с.

10. Окислительная модификация белков сыворотки крови человека. Методы ее определения / Е. Е. Дубинина, С. О. Бурмистров, Д. А. Ходов, И. С. Поротов // Вопр. Мед. Химии. - 1995. - Т. 42, № 1. - С. 24-26.

11. Щербань Н. Г. Лабораторные методики для изучения состояния антиоксидантной системы организма и уровня перекисного окисления липидов : методические рекомендации для докторантов, аспирантов, магистрантов / Н. Г. Щербань, Т. И. Горбач, Н. Р. Гусева. - Харьков : ХНМУ, 2014. - 36 с.

12. Лапач С. Н. Статистические методы в медикобиологических исследованиях с использованием Excel/ С. Н. Лапач, А. В. Чубенко, П. Н. Бабич. - Киев : Моріон, 2000. -320 c.

\section{REFERENCES}

1. Todurov, B.M., Kuzmych, I.M., \& Tarabrin, O.O. (2015). Porushennia funktsii tsentralnoi nervovoi systemy pislia operatsii zi shtuchnym krovoobihom u patsiientiv z nyzkoiu fraktsiieiu vykydu livoho shlunochka [Dysfunction of the central nervous system after operations with artificial circulation in patients with low left ventricular ejection fraction]. Klinichna anesteziolohiia ta intensyvna terapiia Clinical Anesthesiology and Intensive Care, 2, 82-90 [in Ukrainian].

2. Reineke, D., Winkler, B., \& Konig, T. (2015). Minimized extracorporeal circulation does not impair cognitive brain function after coronary artery bypass grafting. Interactive Cardiovascular and Thoracic Surgery, 20(1), 68-73.

3. Mankovsky, D.S. (2021). Hipoksychno-ishemichni urazhennia holovnoho mozku: prohnostychna tsinnist kliniko-anamnestychnykh faktoriv dlia otsinky yikh ryzyku pry kardiokhirurhichnykh vtruchanniakh z vykorystanniam shtuchnoho krovoobihu [Hypoxic-ischemic brain lesions: prognostic value of clinical and anamnestic factors to assess their risk in cardiac surgery using artificial circulation]. The world of science and innovation - 12th International scientific and practical conference. (pp. 232-237). Cognum Publishing House: London, United Kingdom. [in Ukrainian].

4. Mankovsky, D.S. (2021). Tserebralnyi krovoobih ta faktory ryzyku formuvannia hipoksychno-ishemichnykh urazhen holovnoho mozku u kardiokhirurhichnykh patsiientiv pry vykorystanni shtuchnoho krovoobihu [Cerebral circulation and risk factors for the formation of hypoxicischemic brain lesions in cardiac surgery patients using artificial circulation]. Vitchyzniana nauka - perspektyvy ta innovatsii - Domestic science - prospects and innovations: Collection of abstracts of scientific works of the international scientific-practical conference. (pp. 22-26). Kyiv: "Kyivskyi medychnyi naukovyi tsentr» [in Ukrainian].

5. An, N., \& Yu, W.F. (2017). Difficulties in Understanding Postoperative Cognitive Dysfunction. Journal of Anesthesia \& Perioperative Medicine. 4, 87-94.

6. Scharbarg, E., Daenens, M., \& Lemaitre, F. (2016). Astrocyte-derived adenosine is central to the hypnogenic effect of glucose. Scientific Reports, 6. 191-207. doi: 10.1038/ srep19107

7. Kok, W.F., van Harten, A.E., \& Koene, B.M. (2014). A pilot study of cerebral tissue oxygenation and postoperative cognitive dysfunction among patients undergoing coronary artery bypass grafting randomised to surgery with or without cardiopulmonary bypass. Anaesthesia. 69, 613-622. 
Огляди літератури, оригінальні дослідження, погляд на проблему, випадок з практики, короткі повідомлення

8. Ostapchenko, L.I., \& Hrebinyk, D.M. (2014). Biokhimichni mekhanizmy zahybeli klityn: molekuliarni mekhanizmy zahybeli klityn Kurs lektsii zi spetskursu [Biochemical mechanisms of cell death: molecular mechanisms of cell death. Course of lectures on a special course]. Kyiv: Instytut biolohii [in Ukrainian].

9. Ushakova, H.O., Babets, Ya.V., \& Kyrychenko, S.V. (2017). Molekuliarni mekhanizmy rozvytku entsefalopatii [Molecular mechanisms of encephalopathy]. Dnipro: DNU imeni Olesia Honchara [in Ukrainian].

10. Dubynyna, E.E., Burmystrov, S.O., Khodov, D.A., \& Porotov, Y.S. (1995) Okislitelnaia modyfykatsyia belkov syvorotky krovy cheloveka. Metody yeyio opredelenyia [Oxidative modification of human serum proteins. Methods of its definition]. Voprosy medytsynskoi khymyy -
Questions of Medical Chemistry, 1. 24-26 [in Russian].

11. Shcherban, N.H., Horbach, T.Y., \& Huseva, N.R. (2014). Laboratornye metodyky dlia yzuchenyia sostoianyia antyoksydantnoi systemb orhanyzma y urovnia perekysnoho okyslenyia lypydov [Laboratory methods for the recovery of the antioxidant system of the body and the level of peroxidation of lipids]. Metodycheskye rekomendatsyy dlia doktorantov, aspyrantov, mahystrantov - Methodical recommendations for doctoral students, postgraduates, undergraduates. Kharkov: KhNMU [in Russian].

12. Lapach, S.N., Chubenko, A.V., \& Babych, P.N. (2000). Statystycheskie metody $v$ mediko-byolohycheskykh isledovanyiakh s ispolzovaniem Excel [Statistical Methods in Life Sciences Research Using Excel]. Kyev: «Morion» [in Russian].

\title{
OXIDATIVE DESTRUCTION OF PROTEINS IN HYPOXIC-ISCHEMIC BRAIN LOSSES AT THE STAGES OF CARDIOSURGICAL INTERVENTIONS WITH THE USE OF ARTIFICIAL BLOOD CIRCULATION
}

\author{
State Institution "Heart Institute of the Ministry of Health of Ukraine"
}

@D. S. Mankovsky

SUMMARY. The role of free radical oxidation of blood proteins in the mechanisms of development of hypoxicischemic lesions (SMI) of the brain (GM) and in the effectiveness of the blood-encephalic barrier (HEB) depends on endothelial cells, astrocytes and pericytes, dysfunction of which causes dysfunction. due to oxidation of protein fragments.

The aim - to study the peculiarities of oxidation of protein fragments of cells and nucleic acids in patients with hypoxic-ischemic lesions before and after cardiac surgery using artificial circulation.

Material and Methods. The results of examination of 38 patients with hypoxic-ischemic brain lesions after cardiac surgery; diagnosis of neurological status were performed according to clinical protocols. ) reactions at the preoperative (3-5 days) and postoperative (5-7 days) stages. The content of protein components in the serum - 2,4 - dinitrophenylhydrozones (DNFG) was studied.

Results. Spontaneous OMB at the stages of CKD is characterized by significant $(p<0.001)$ changes in the accumulation of both aldehyde and carbonyl products, as well as in changes in the degree (depth) of protein destruction. In the induced OMB reactions revealed an increase (from $(0.303 \pm 0.007)$ USD / mg protein to $(0.396 \pm 0.003$ USD / mg protein) degree (depth) of protein destruction due to protein fragments of medium size and a significant increase in specific weight of fragments of small size, which is the most informative sign of the impact on the metabolic reserves of OMB in patients.

Conclusions. At the stages of cardiac surgery, the preconditions are formed that contribute to the intensification of the OMB process of blood plasma and OMNC. The peculiarity of changes in the state of OMNC and OMB is the most pronounced increase in their content in the postoperative period against the background of relative growth of aldehyde and carbonyl oxidation products with redistribution of the degree (depth) of ODB in spontaneous and especially induced reactions. The above indicates an increase in the manifestations of destruction and intensification of OMB with the simultaneous accumulation of oxidation reserves of protein fragments of blood plasma in the postoperative period.

KEY WORDS: hypoxic-ischemic brain lesions; cardiac surgery; oxidative modification of proteins.

Отримано 09.09.2021 